\title{
Preparation of Lanthanum Oxide and Lanthanum Oxycarbonate Layers on Titanium by Electrodeposition with Organic Solution
}

\author{
Jeonghee Choi and Yong Hee Chung \\ Department of Chemistry, Hallym University, 1 Hallymdaehak-gil, Chuncheon 24252, Republic of Korea \\ Correspondence should be addressed to Yong Hee Chung; yhchung@hallym.ac.kr
}

Received 25 March 2016; Accepted 4 July 2016

Academic Editor: Lihong Jing

Copyright ( 92016 J. Choi and Y. H. Chung. This is an open access article distributed under the Creative Commons Attribution License, which permits unrestricted use, distribution, and reproduction in any medium, provided the original work is properly cited.

Layers of lanthanum oxide and lanthanum oxycarbonate were prepared on titanium by electrodeposition with organic solution. Four voltages ranging from 200 to $1000 \mathrm{~V}$ were applied for the electrodeposition at three concentrations of lanthanum ions. The organic solution was isobutanol and titanium foils were used as anodes and cathodes. Currents were monitored during the electrodeposition. Deposition layers were calcined at $700 \mathrm{~K}$ for $30 \mathrm{~min}$ or at $900 \mathrm{~K}$ for 60 and $200 \mathrm{~min}$. The morphology and composition of the deposition layers were examined by scanning electron microscopy (SEM), X-ray diffraction (XRD), and Xray photoelectron spectroscopy (XPS). Calcined deposition layers were assayed to be lanthanum oxycarbonate and lanthanum oxide. The average crystallite size was in the vicinity of $8 \mathrm{~nm}$. Sizes of lanthanum oxycarbonate agglomerates in layers with 30 min electrodeposition and calcination at $700 \mathrm{~K}$ were ranging from 25 to $75 \mathrm{~nm}$. Yields of lanthanum oxycarbonate at three concentrations of lanthanum ions were shown to be better at $400 \mathrm{~V}$.

\section{Introduction}

Targets of actinides with a thickness of $0.24-0.57 \mathrm{mg} / \mathrm{cm}^{2}$ were used in nuclear reactions induced by heavy ions [1], while those of lanthanum oxide of $1.2 \mathrm{~g} / \mathrm{cm}^{2}$ [2], zirconium of $12 \mathrm{mg} / \mathrm{cm}^{2}$, and hafnium of $31 \mathrm{mg} / \mathrm{cm}^{2}$ were used in proton-induced reactions [3]. Targets of lanthanum oxide and lanthanum oxycarbonate with a thickness of 0.24$3.0 \mathrm{mg} / \mathrm{cm}^{2}$ can be used to explore cross sections of protoninduced reactions with lanthanum to produce ${ }^{139} \mathrm{Ce}$ in the energy range of $20-35 \mathrm{MeV}$, which have not been reported in previous studies [4-6].

Lanthanum oxide thin films have been prepared by chemical vaporization, spray pyrolysis, atomic layer epitaxy, and dual plasma deposition [7-10]. Lanthanum oxide and lanthanum oxycarbonate can be prepared by a thermal decomposition [11-16]. Lanthanum oxide films were reported to reveal hemocompatibility properties suitable for biomedical materials [10]. Photocatalytic activity of lanthanum oxycarbonate studied in a degradation of methyl orange aqueous solution under ultraviolet light irradiation can be applied to wastewater purification [11]. Lanthanum oxycarbonate can be used for sensing chemoresistive $\mathrm{CO}_{2}$ gas [16]. Thin layers of actinides can be prepared by molecular plating that is the electrodeposition performed in organic solutions $[1,17,18]$. The electrodeposition of actinides in aqueous or organic solutions has been known to present a complicated mechanism $[19,20]$. This is due to the fact that the actinide elements are too electropositive to be reduced as metals at the cathode. The electrodeposition from aqueous solutions of actinides happens by a precipitation process in a layer of hydroxyl ions formed at the cathode surface and results in the oxyhydroxide compounds. Since the lanthanum element is very electropositive just like the actinide elements, its hydrolytic compound could be produced by molecular plating and be changed to lanthanum oxide by calcination.

In the present work lanthanum oxide and lanthanum oxycarbonate layers of various thicknesses were prepared on titanium foils using electrodeposition in organic solutions of three concentrations at high voltages. Effects of electrodeposition concentration, time, and voltage on morphology of calcined layers were investigated. Titanium was chosen as 


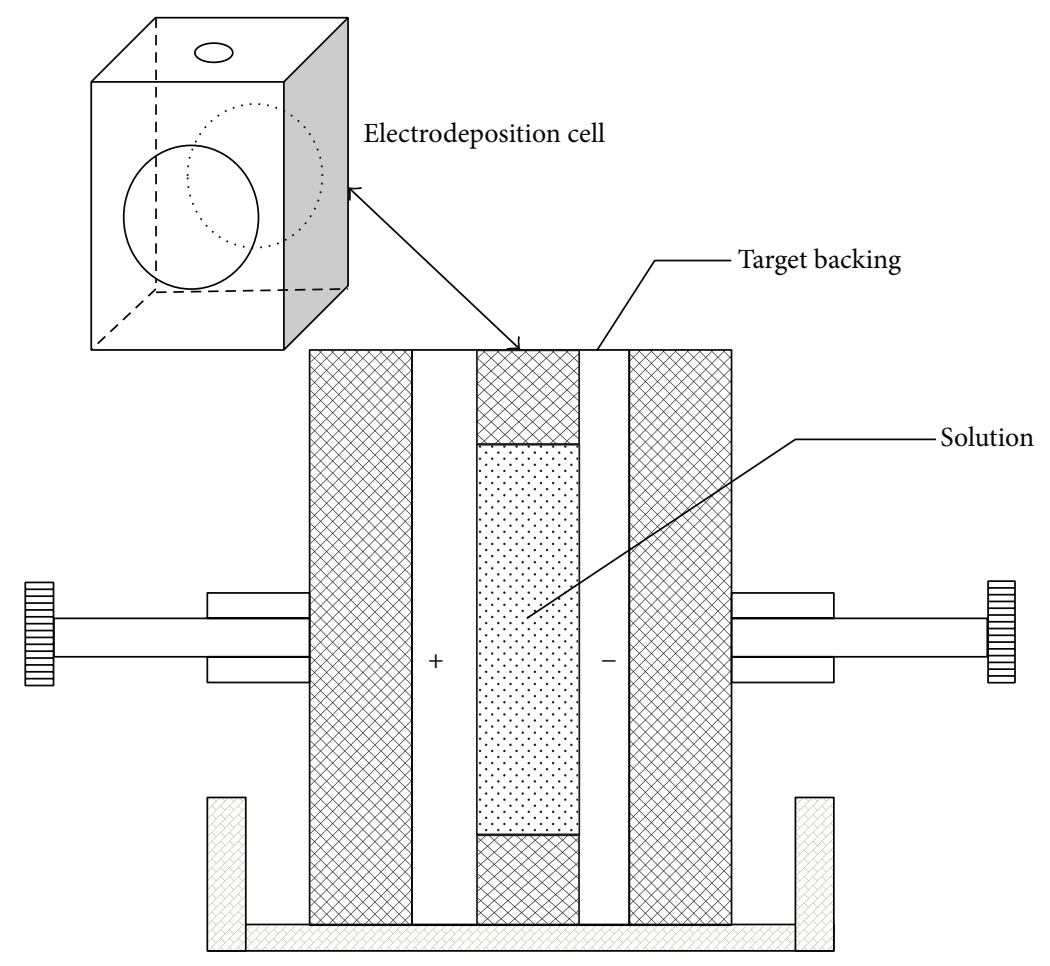

FIGURE 1: Schematic of an electrodeposition cell.

electrode due to the fact that it could be used to precisely determine the proton energy in proton-induced reactions $[21,22]$.

\section{Experimental}

Lanthanum nitrate hexahydrate (99.999\%, Alfa Aesar) powder was dissolved in a minimal amount of distilled water and further in isobutanol. The aqueous-organic mixture was evaporated by heating above $94^{\circ} \mathrm{C}$ to its nearly dried state, whose composition was examined by X-ray photoelectron spectroscopy (XPS, Thermo Scientific K-Alpha ${ }^{+}$spectrometer) with an Al K $\alpha$ microfocused monochromator. The dried lanthanum nitrate precursor was dissolved in isobutanol and the resulting solutions with concentrations of lanthanum ions of $0.046,0.092$, and $2.0 \mathrm{mg} / \mathrm{mL}$, corresponding to $0.33,0.66$, and $14.5 \mathrm{mM}$, respectively, were used in the electrodeposition. The highest concentration was chosen in order to speed up electrodeposition for thicker targets with rather uniform surfaces and study how morphology of deposition layers changes with the higher concentration.

The electrodeposition was carried out at room temperature in a cell as shown in Figure 1. The cell was made of Teflon as in the other study [1]. Polished titanium foils were used as anodes and cathodes whose typical thickness was $11.4 \mu \mathrm{m}$. The titanium electrodes were washed consecutively by nitric acid, distilled water, and ethanol before being assembled into the cell. The electrodeposition area was $3.14 \mathrm{~cm}^{2}$ and the distance between the electrodes was $10 \mathrm{~mm}$. The cell was filled up to $3.5 \mathrm{~mL}$ with the organic lanthanum nitrate solution. Voltages of the electrodeposition performed at room temperature were $200,400,600$, and $1000 \mathrm{~V}$. The electrodeposition times were $30 \mathrm{~min}$ for $0.046 \mathrm{mg} / \mathrm{mL}, 30 \mathrm{~min}$ and $1 \mathrm{hr}$ for $0.092 \mathrm{mg} / \mathrm{mL}$, and $30 \mathrm{~min}$ and $8 \mathrm{hr}$ for $2.0 \mathrm{mg} / \mathrm{mL}$. The currents were monitored during the deposition time. Layers of deposited lanthanum compounds were washed consecutively by distilled water and ethanol. After being washed they were kept in ethanol for $24 \mathrm{hr}$ in order to remove the residual nitrate electrolyte and dried in a drying oven at $50^{\circ} \mathrm{C}$. The electrodeposited layers were calcined at $700 \mathrm{~K}$ for $30 \mathrm{~min}$ or at $900 \mathrm{~K}$ for 60 or $200 \mathrm{~min}$. Figure 2 shows the steps involved for syntheses of lanthanum oxide and lanthanum oxycarbonate. Deposition layers with thicknesses thicker than $2.0 \mathrm{mg} / \mathrm{cm}^{2}$ were prepared typically by 5 or more depositions where a calcination process was performed at $700 \mathrm{~K}$ for $30 \mathrm{~min}$ right after each deposition.

Morphology and surface compositions of electrodeposition layers were examined by scanning electron microscopy (SEM, Hitachi S-4300) and X-ray photoelectron spectroscopy (XPS, Thermo Scientific K-Alpha). Their corresponding compositions and sizes were determined from measurements by X-ray diffraction (XRD, PANalytical X'pert PRO MPD) with wavelength of $\mathrm{Cu} \mathrm{K}, 1.5405 \AA$.

\section{Results and Discussion}

XPS spectrum of the lanthanum nitrate precursor with isobutanol dried on a Ti foil is shown in Figure 3(a). XPS spectra of electrodeposition layers are shown in Figures 3(b)3(d) which were obtained without calcination, with $30 \mathrm{~min}$ calcination at $700 \mathrm{~K}$, and with $1 \mathrm{hr}$ calcination at $900 \mathrm{~K}$, respectively. Figure 3(a) shows photoelectron peaks of bulk 


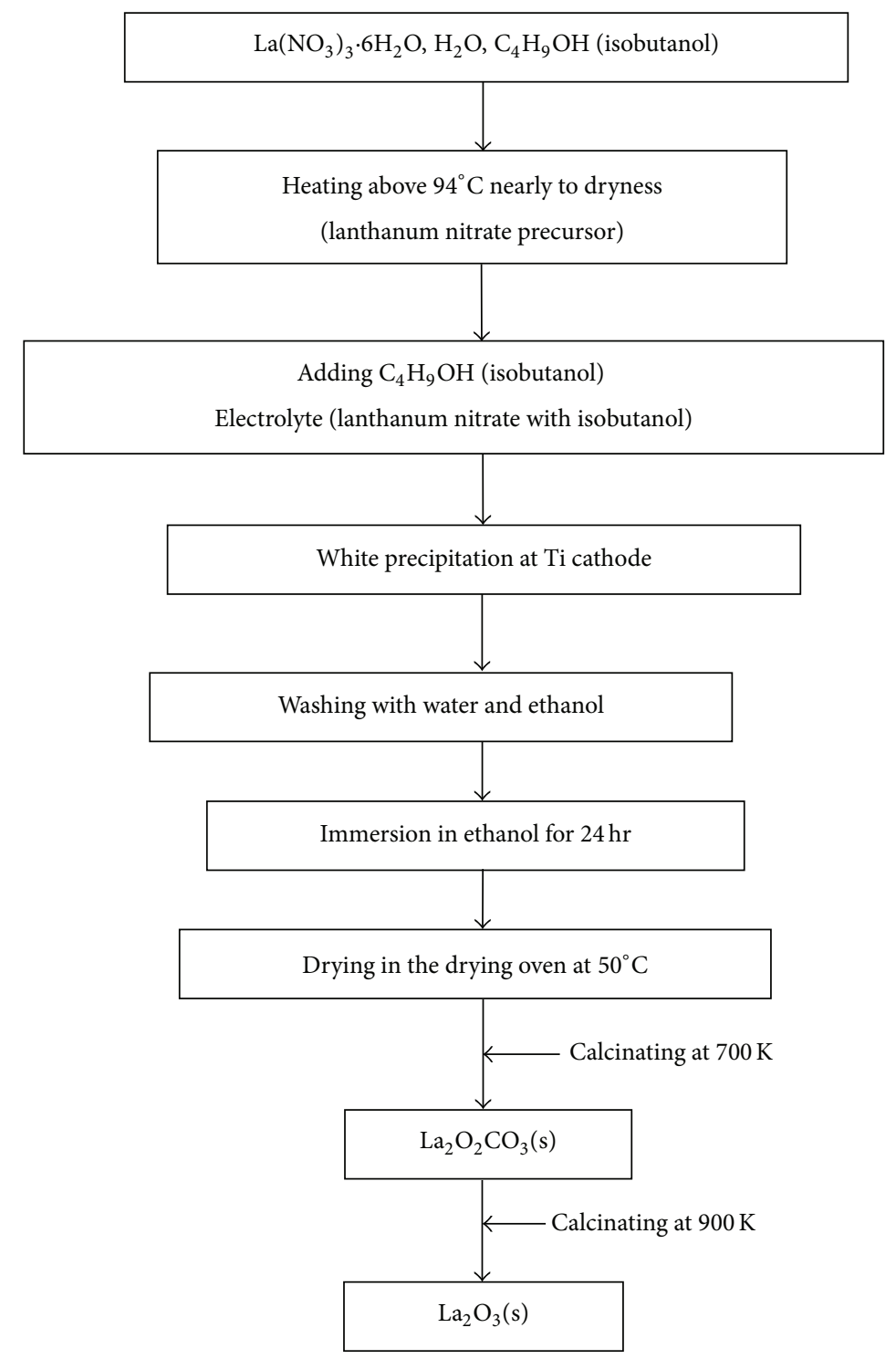

FIgURE 2: Chart for syntheses of lanthanum oxide and lanthanum oxycarbonate.

TABLE 1: Elemental composition (atomic\%) obtained from XPS spectra for lanthanum nitrate precursor and electrodeposition layers.

\begin{tabular}{|c|c|c|c|c|c|}
\hline \multirow{2}{*}{$\begin{array}{l}\text { Major element } \\
\text { (atomic\%) }\end{array}$} & \multirow{2}{*}{ Lanthanum nitrate precursor } & \multicolumn{4}{|c|}{ Layers } \\
\hline & & $\begin{array}{l}\text { Without } \\
\text { calcination }\end{array}$ & $\begin{array}{c}700 \mathrm{~K} \\
30 \mathrm{~m}\end{array}$ & $\begin{array}{c}900 \mathrm{~K} \\
1 \mathrm{hr}\end{array}$ & $\begin{array}{l}900 \mathrm{~K} \\
200 \mathrm{~m}\end{array}$ \\
\hline $\mathrm{La}$ & 4.5 & 11.6 & 15.0 & 14.4 & 18.2 \\
\hline $\mathrm{O}$ & 61.0 & 55.2 & 56.1 & 59.6 & 61.9 \\
\hline $\mathrm{C}$ & 32.8 & 33.2 & 28.9 & 25.9 & 19.9 \\
\hline $\mathrm{N}$ & 1.6 & & & & \\
\hline
\end{tabular}

${ }^{*}$ Titanium excluded in elemental compositions.

La $3 \mathrm{~d}$ and $4 \mathrm{p}, \mathrm{N}$ 1s, O 1s, C 1s, and Ti 2p. The N 1s, O 1s, and C 1 s peaks are mainly due to nitrate and isobutanol. The Ti $2 \mathrm{p}$ peak originates from the Ti foil. Any significant impurities were not found in the organic electrolyte. Figures 3(b)-3(d) show photoelectron peaks of $\mathrm{La} 3 \mathrm{~d}$ and $4 \mathrm{p}, \mathrm{O}$ 1s, and $\mathrm{C} 1 \mathrm{~s}$ and their corresponding elemental compositions are listed in
Table 1. As shown in Figures 3(b)-3(d) and Table 1, the carbon contents in the layers decrease as calcination temperature and time increase. Their corresponding $\mathrm{La} 3 \mathrm{~d}_{5 / 2}$ and $3 \mathrm{~d}_{3 / 2}$ peaks are shown in Figures 4(a) and 4(b).

The $\mathrm{La} 3 \mathrm{~d}_{5 / 2}$ peaks for the lanthanum nitrate precursor and three layers in Figure $4(\mathrm{a})$ are at 839.6, 835.6, 834.5, 


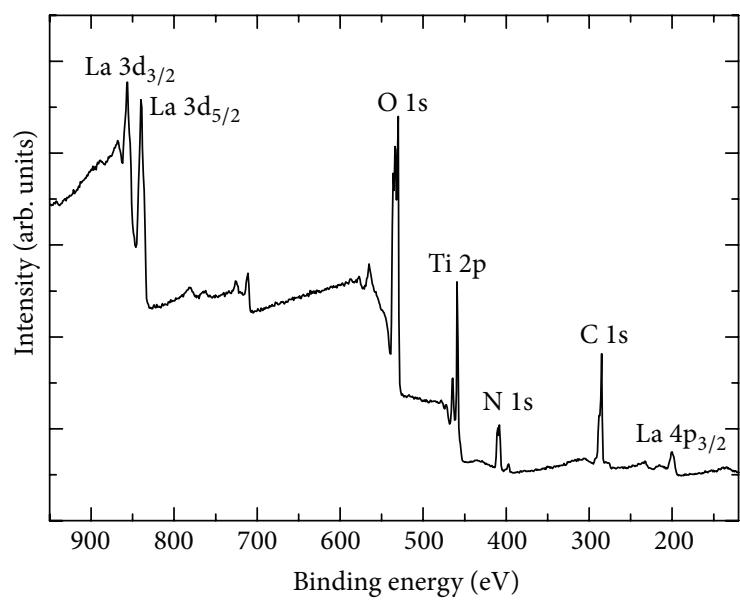

(a)

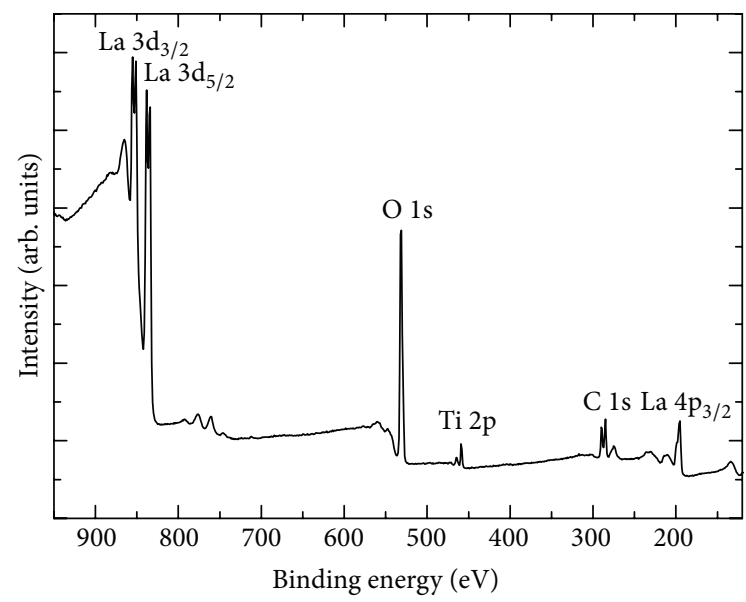

(c)

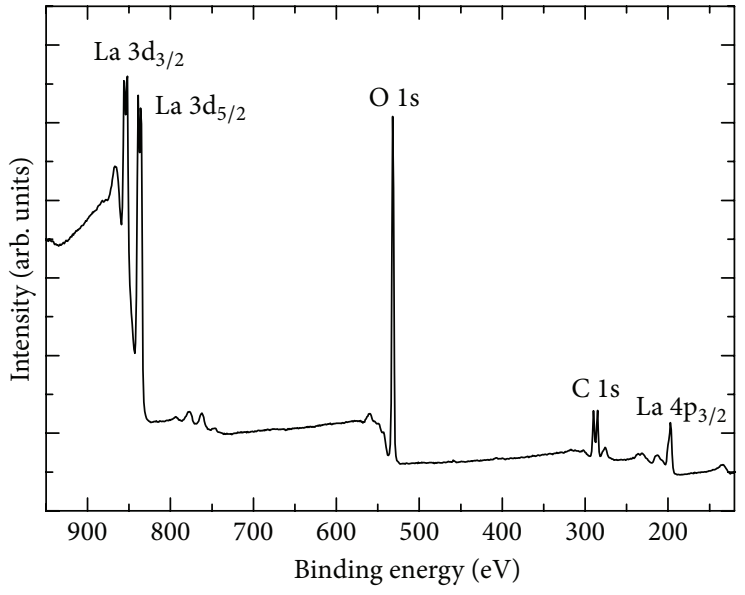

(b)

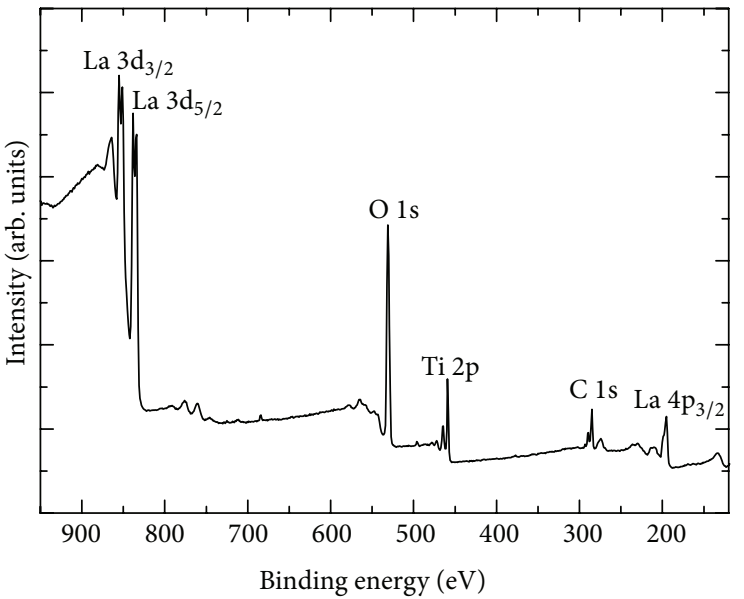

(d)

FIGURE 3: XPS spectra of (a) lanthanum nitrate precursor dried on Ti and layers on Ti electrodeposited at $1000 \mathrm{~V}$ (b) without calcination, (c) calcined at $700 \mathrm{~K}$ for $30 \mathrm{~min}$, and (d) calcined at $900 \mathrm{~K}$ for $1 \mathrm{hr}$.

and $834.4 \mathrm{eV}$, respectively, while their corresponding $3 \mathrm{~d}_{3 / 2}$ peaks in Figure 4(b) are at 856.5, 852.5, 851.4, and $851.2 \mathrm{eV}$, respectively. The La $3 \mathrm{~d}$ peaks for the calcined layers in Figures 4(a) and 4(b) match well within $0.2 \mathrm{eV}$, implying that they have a similar chemical composition. The La $3 \mathrm{~d}$ peaks for the layer without calcination are located at higher binding energies by $1.1-1.3 \mathrm{eV}$, which indicates that its composition is different from those of the calcined layers. The separation between $\mathrm{La} 3 \mathrm{~d}_{5 / 2}$ and $3 \mathrm{~d}_{3 / 2}$ peaks in the layers with or without calcination is $16.8-16.9 \mathrm{eV}$ and the corresponding separation in the lanthanum nitrate precursor is $16.9 \mathrm{eV}$. Both of their satellite peaks for the calcined layers are located at higher binding energies by $3.8-3.9 \mathrm{eV}$, while those for the layer without calcination appear at higher binding energies by $3.3-3.4 \mathrm{eV}$. The broad $\mathrm{La} 3 \mathrm{~d}$ peaks of the lanthanum nitrate precursor in Figures 4(a) and 4(b) reveal its bulk properties.

Figure 5 shows the wide-angle X-ray diffraction (XRD) patterns of three layers on Ti foils electrodeposited for $30 \mathrm{~min}$ at $400 \mathrm{~V}$ (a) without calcination, (b) calcined at $700 \mathrm{~K}$ for $30 \mathrm{~min}$, and (c) calcined at $900 \mathrm{~K}$ for $200 \mathrm{~min}$. The layer without calcination in Figure 5(a) shows hexagonal Ti with crystal faces of (100), (002), (101), and (102) due to the Ti foil. Measured relative intensities of diffraction peaks in Figure $5(\mathrm{~b})$ at $2 \theta=13.0^{\circ}, 22.8^{\circ}, 26.3^{\circ}, 29.5^{\circ}, 31.2^{\circ}, 40.1^{\circ}, 41.3^{\circ}$, $44.4^{\circ}, 52.4^{\circ}$, and $54.6^{\circ}$ were $75.1,39.3,17.1,100,26.8,36.7$, $13.5,17.9,8.2$, and $10.7 \%$, respectively. All of them can be indexed mainly to the monoclinic structure of $\mathrm{La}_{2} \mathrm{O}_{2} \mathrm{CO}_{3}$ with lattice constants $a=4.0803 \AA, b=13.5090 \AA$, and $c=4.0720 \AA$ (reference code $00-048-1113$ ) and partially to the tetragonal structure of $\mathrm{La}_{2} \mathrm{O}_{2} \mathrm{CO}_{3}$ with lattice constants $a=$ $4.0630 \AA, b=4.0630 \AA$, and $c=13.5000 \AA$ (reference code 00-023-0320), implying that the layer calcined at $700 \mathrm{~K}$ for $30 \mathrm{~min}$ is $\mathrm{La}_{2} \mathrm{O}_{2} \mathrm{CO}_{3}$ with mixed monoclinic and tetragonal phases. The average particle size was estimated using Scherrer equation $[11,23]$ :

$$
D=\frac{K \lambda}{\beta \cos \theta},
$$

where $D$ is the average particle size, $K$ is the dimensionless shape factor whose typical value is about $0.9, \lambda$ is the $\mathrm{X}$ ray wavelength used in $\mathrm{XRD}\left(\mathrm{Cu} \mathrm{K}_{\alpha}=1.5405 \AA\right), \beta$ is the broadening of the observed diffraction line at half the 


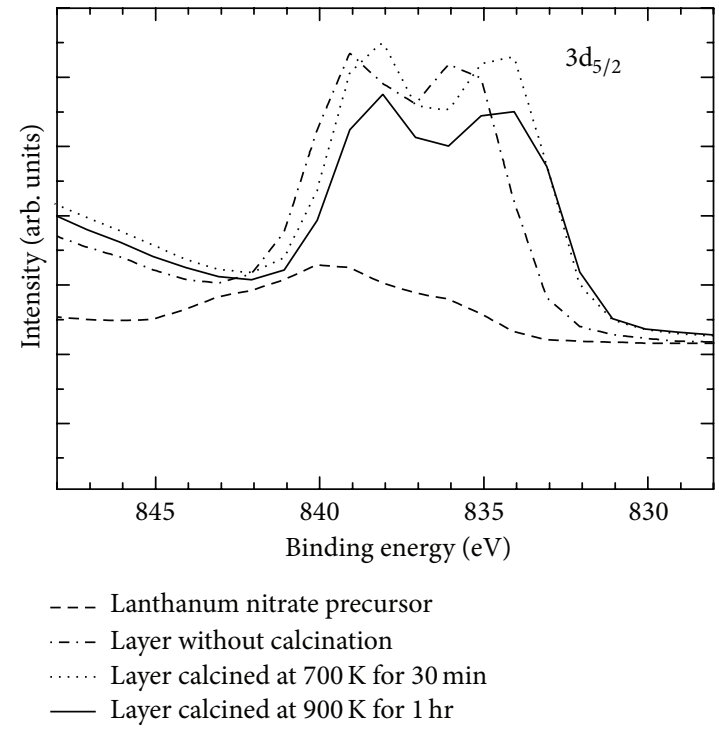

(a)

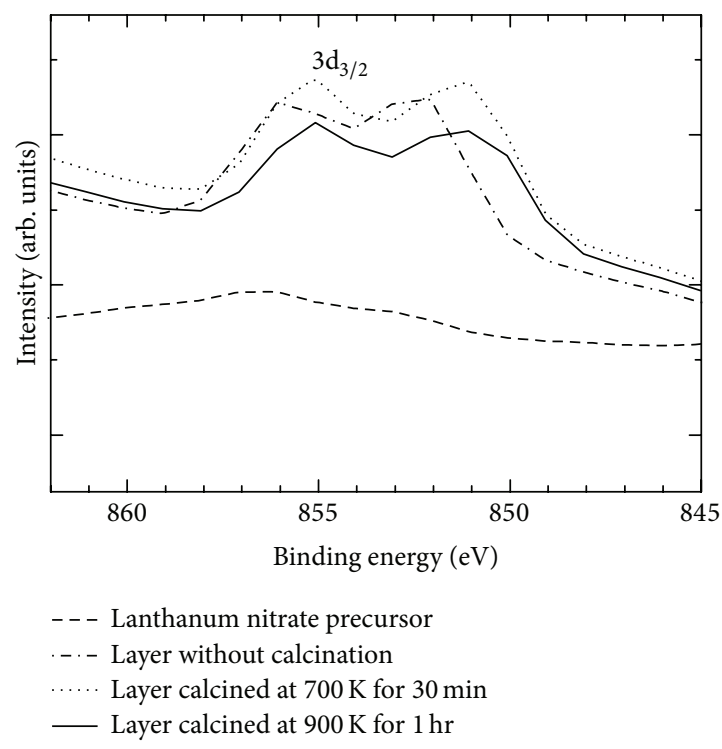

(b)

FiguRE 4: XPS spectra of (a) La 3d $\mathrm{d}_{5 / 2}$ and (b) La 3d $\mathrm{d}_{3 / 2}$ peaks in Figures 3(a)-3(d): dashed lines (Figure 3(a)); dash-and-dot lines (Figure 3(b)); dotted lines (Figure 3(c)); and solid lines (Figure 3(d)).

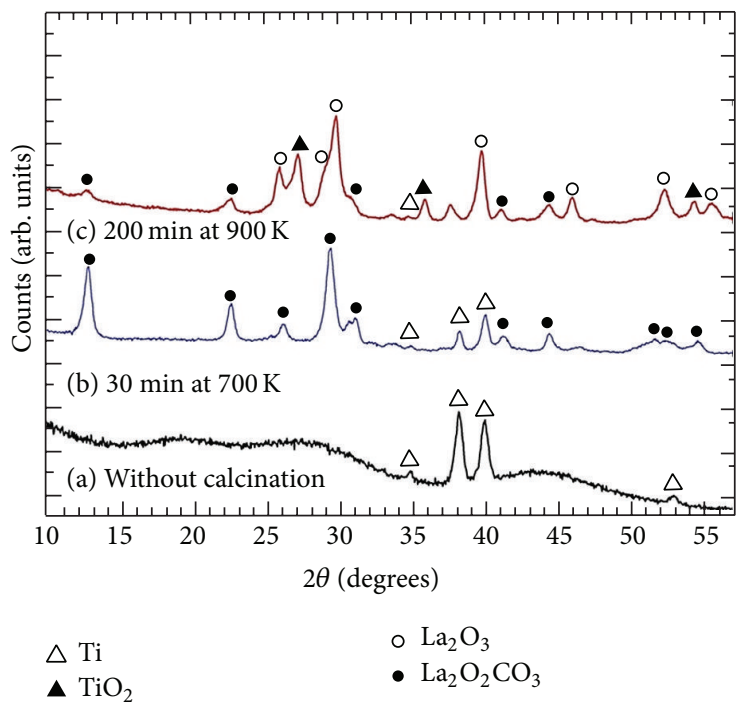

FiguRE 5: X-ray diffraction patterns of three layers on Ti electrodeposited at $400 \mathrm{~V}$ : (a) without calcination and with calcination (b) at $700 \mathrm{~K}$ for $30 \mathrm{~min}$ and (c) at $900 \mathrm{~K}$ for $200 \mathrm{~min}$.

maximum intensity in radians, and $\theta$ is the Bragg angle. Using the peaks at $2 \theta=13.0^{\circ}, 22.8^{\circ}, 26.3^{\circ}, 29.5^{\circ}, 31.2^{\circ}, 40.1^{\circ}, 41.3^{\circ}$, $44.4^{\circ}, 52.4^{\circ}$, and $54.6^{\circ}$, the average crystallite size of the layer calcined at $700 \mathrm{~K}$ for $30 \mathrm{~min}$ was deduced to be $16 \pm 3 \mathrm{~nm}$.

The XRD pattern of the layer calcined at $900 \mathrm{~K}$ for 200 min shown in Figure 5(c) confirms partial decomposition of $\mathrm{La}_{2} \mathrm{O}_{2} \mathrm{CO}_{3}$ to $\mathrm{La}_{2} \mathrm{O}_{3}$. The decomposition reaction can be written as $\mathrm{La}_{2} \mathrm{O}_{2} \mathrm{CO}_{3}(\mathrm{~s}) \rightarrow \mathrm{La}_{2} \mathrm{O}_{3}(\mathrm{~s})+\mathrm{CO}_{2}(\mathrm{~g})$, which was reported to occur above $993 \mathrm{~K}$ [12]. Diffraction peaks in Figure $5(\mathrm{c})$ at $2 \theta=27.6^{\circ}, 36.2^{\circ}, 41.4^{\circ}$, and $54.6^{\circ}$ can be indexed to the tetragonal structure of $\mathrm{TiO}_{2}$ produced from calcination of Ti foil at $900 \mathrm{~K}$. Dominant diffraction peaks at $2 \theta=26.1^{\circ}$, $29.3^{\circ}, 29.9^{\circ}, 39.8^{\circ}, 46.0^{\circ}, 52.2^{\circ}, 55.5^{\circ}$, and $55.9^{\circ}$ can be indexed to the hexagonal structure of $\mathrm{La}_{2} \mathrm{O}_{3}$ with lattice constants $a$ $=3.9373 \AA, b=3.9373 \AA$, and $c=6.1299 \AA$ (reference code 01$074-2430$ ), while significant peaks at $2 \theta=12.9^{\circ}, 22.7^{\circ}, 31.0^{\circ}$, $39.9^{\circ}$, and $44.4^{\circ}$ can be indexed to the monoclinic structure of $\mathrm{La}_{2} \mathrm{O}_{2} \mathrm{CO}_{3}$. The scaling factors of $\mathrm{La}_{2} \mathrm{O}_{3}$ and $\mathrm{La}_{2} \mathrm{O}_{2} \mathrm{CO}_{3}$ were estimated to be 1.024 and 0.399 , respectively, implying that the layer calcined at $900 \mathrm{~K}$ for $200 \mathrm{~min}$ consists of $72 \% \mathrm{La}_{2} \mathrm{O}_{3}$ and $28 \% \mathrm{La}_{2} \mathrm{O}_{2} \mathrm{CO}_{3}$. Using the peaks at $2 \theta=26.1^{\circ}, 29.3^{\circ}$, $29.9^{\circ}, 46.0^{\circ}, 52.2^{\circ}$, and $55.5^{\circ}$ for $\mathrm{La}_{2} \mathrm{O}_{3}$, the corresponding average crystallite size was deduced to be $9 \pm 3 \mathrm{~nm}$. Using the peaks at $2 \theta=12.9^{\circ}, 22.7^{\circ}, 31.0^{\circ}$, and $44.4^{\circ}$ for $\mathrm{La}_{2} \mathrm{O}_{2} \mathrm{CO}_{3}$, 


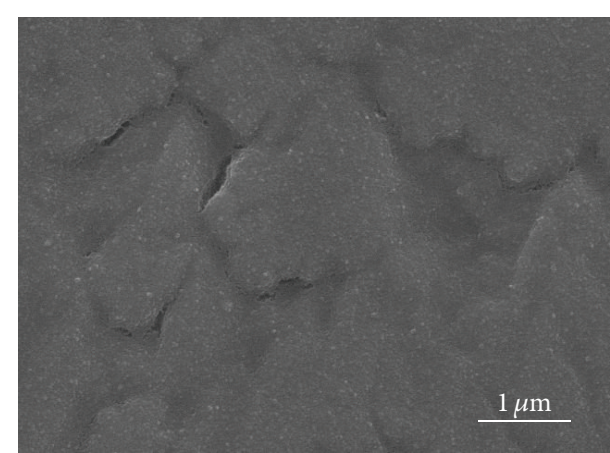

(a)

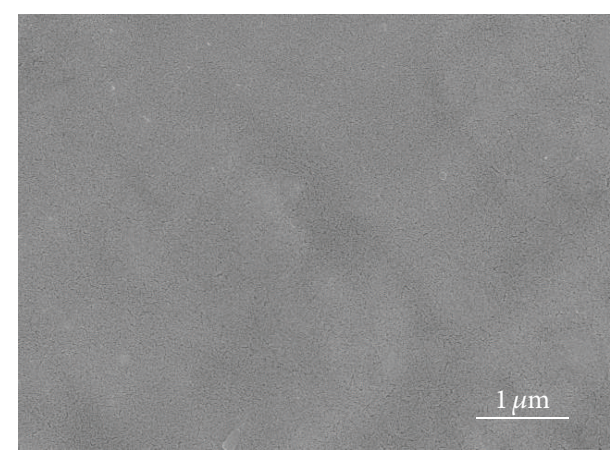

(c)

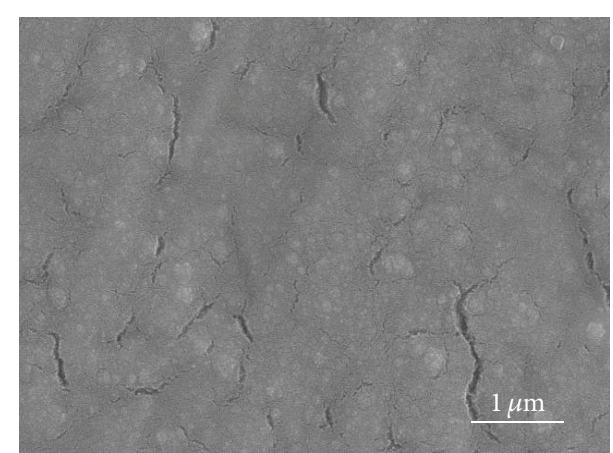

(b)

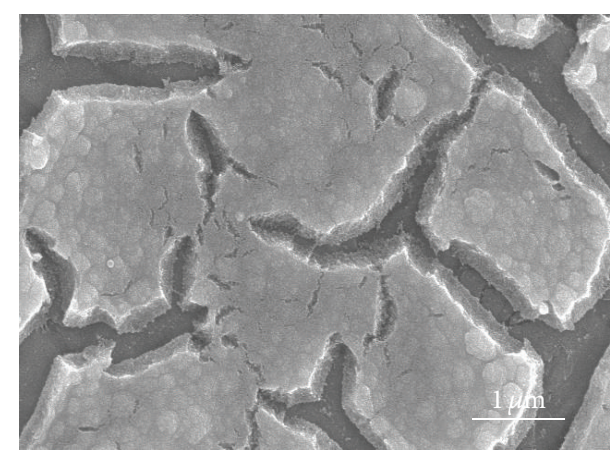

(d)

FIGURE 6: SEM micrographs of $\mathrm{La}_{2} \mathrm{O}_{2} \mathrm{CO}_{3}$ layers calcined at $700 \mathrm{~K}$ for $30 \mathrm{~min}$ after $30 \mathrm{~min}$ electrodeposition of $0.046 \mathrm{mg} / \mathrm{mL}^{\circ} \mathrm{La}{ }^{3+}$ ions on Ti at (a) $200 \mathrm{~V}$, (b) $400 \mathrm{~V}$, (c) $600 \mathrm{~V}$, and (d) $1000 \mathrm{~V}$.

the corresponding average crystallite size calcined at $900 \mathrm{~K}$ for $200 \mathrm{~min}$ was deduced to be $8 \pm 1 \mathrm{~nm}$. The average particle size of $\mathrm{La}_{2} \mathrm{O}_{2} \mathrm{CO}_{3}$ nanoparticles decreases from 16 to $8 \mathrm{~nm}$ as calcination temperature and time increase from 700 to $900 \mathrm{~K}$ and from 30 to $200 \mathrm{~min}$, respectively.

SEM micrographs of $\mathrm{La}_{2} \mathrm{O}_{2} \mathrm{CO}_{3}$ layers on Ti foils calcined at $700 \mathrm{~K}$ for $30 \mathrm{~min}$ after $30 \mathrm{~min}$ electrodepositions of $\mathrm{La}^{3+}$ ions of $0.046,0.092$, and $2.0 \mathrm{mg} / \mathrm{mL}$ at $200,400,600$, and $1000 \mathrm{~V}$ are shown in Figures 6-8, respectively. SEM micrographs of $\mathrm{La}_{2} \mathrm{O}_{2} \mathrm{CO}_{3}$ layers of the corresponding concentrations obtained by two electrodeposition and calcination steps are shown in Figures 9-11. The layers in Figures 9-11 were obtained by performing two steps of the electrodeposition and subsequent $30 \mathrm{~min}$ calcination and the corresponding deposition times were 30 and $30 \mathrm{~min}, 30 \mathrm{~min}$ and $1 \mathrm{hr}$, and $30 \mathrm{~min}$ and $8 \mathrm{hr}$, respectively. Figure 6 shows lanthanum oxycarbonate layers containing agglomerates with sizes ranging between 37 and $75 \mathrm{~nm}$. Lanthanum oxycarbonate layers in Figure 7 contain agglomerates with size ranging between 30 and $75 \mathrm{~nm}$, while those in Figure 8 have agglomerates with size ranging between 25 and $62 \mathrm{~nm}$. Figures 9-11 show the larger agglomerates whose sizes increase to 66-330, 661300 , and $44-2200 \mathrm{~nm}$, respectively. Lanthanum oxycarbonate nanoparticles with agglomerates of various sizes can be tested as sensing materials in photocatalytic activity and wastewater purification.

Currents of $30 \mathrm{~min}$ electrodepositions at 200, 400, 600, and $1000 \mathrm{~V}$ with $0.046,0.092$, and $2.0 \mathrm{mg} / \mathrm{mL}$ of $\mathrm{La}^{3+}$ ions are shown in Figures 12-14, respectively. Figure 12 shows that currents start to increase during the process but at $600 \mathrm{~V}$ start to fall after about $6 \mathrm{~min}$. The corresponding accumulated current is highest at $400 \mathrm{~V}$ and lowest at $200 \mathrm{~V}$. Figure 13 shows that currents start to increase during the process but at $400 \mathrm{~V}$ start to fall after about $10 \mathrm{~min}$ and to sharply drop after about $20 \mathrm{~min}$. The corresponding accumulated current is highest at $1000 \mathrm{~V}$ and lowest at $200 \mathrm{~V}$. Figure 14 shows that all currents start to increase during the process. The values of the corresponding accumulated currents are close to one another.

Yields of 30 min electrodepositions at 200, 400,600, and $1000 \mathrm{~V}$ with $0.046,0.092$, and $2.0 \mathrm{mg} / \mathrm{mL}$ of $\mathrm{La}^{3+}$ ions are shown in Figures 15-17, respectively. The yields in Figure 15 are close to $\sim 70 \%$ at higher voltages which appears to be slightly higher than $\sim 60 \%$ at $200 \mathrm{~V}$. The corresponding thicknesses were $0.04-0.05 \mathrm{mg} / \mathrm{cm}^{2}$. Figures 16 and 17 show that the yields are highest at $400 \mathrm{~V}$. The corresponding thicknesses in Figures 16 and 17 were $0.09-0.13$ and $0.38-0.46 \mathrm{mg} / \mathrm{cm}^{2}$, respectively. The yields of lanthanum oxycarbonate nanoparticles at three concentrations of lanthanum ions were shown to be better at $400 \mathrm{~V}$, even though their morphology varies slightly with the voltage. Using 5 or 6 steps of the $30 \mathrm{~min}$ electrodeposition and subsequent $30 \mathrm{~min}$ calcination process, thicker layers of $\mathrm{La}_{2} \mathrm{O}_{2} \mathrm{CO}_{3}$ were prepared at 200, 400, 600, and $1000 \mathrm{~V}$ and the corresponding thicknesses were 2.0, $2.3,2.3$, and $2.0 \mathrm{mg} / \mathrm{cm}^{2}$, respectively. The results are shown in Figure 18. The layer obtained at $400 \mathrm{~V}$ is covered with 


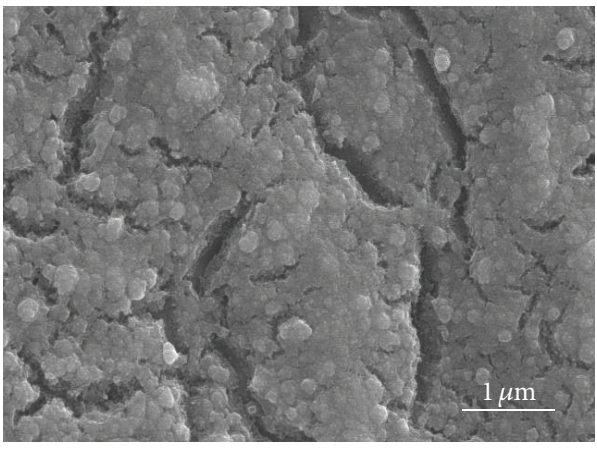

(a)

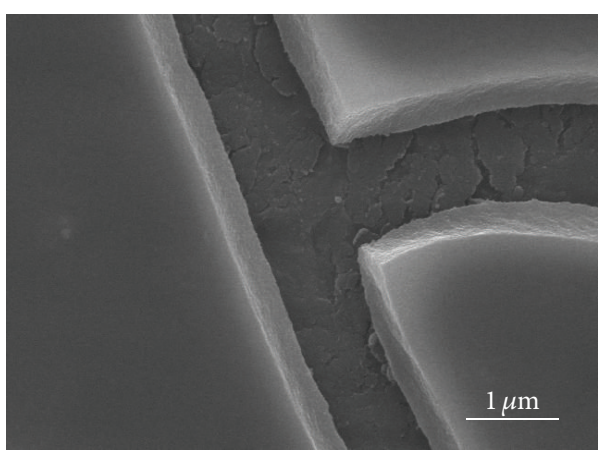

(c)

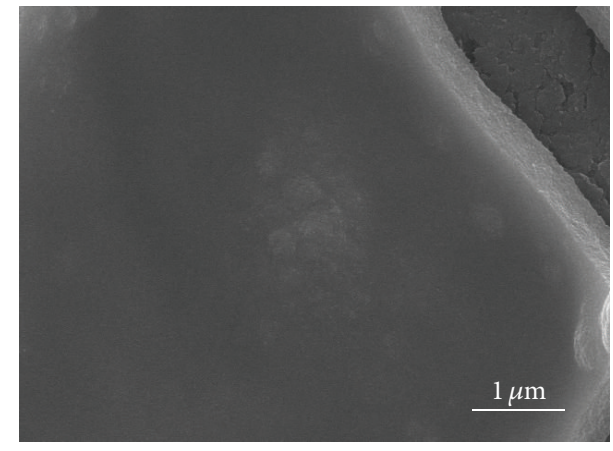

(b)

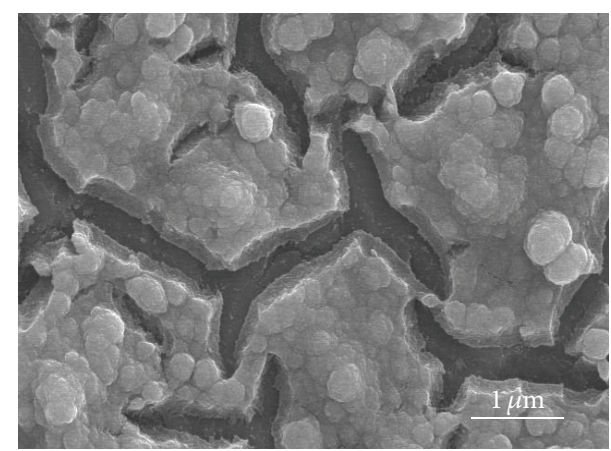

(d)

FIgURE 7: SEM micrographs of $\mathrm{La}_{2} \mathrm{O}_{2} \mathrm{CO}_{3}$ layers calcined at $700 \mathrm{~K}$ for $30 \mathrm{~min}$ after $30 \mathrm{~min}$ electrodeposition of $0.092 \mathrm{mg} / \mathrm{mL}$ of La ${ }^{3+}$ ions on Ti at (a) $200 \mathrm{~V}$, (b) $400 \mathrm{~V}$, (c) $600 \mathrm{~V}$, and (d) $1000 \mathrm{~V}$.

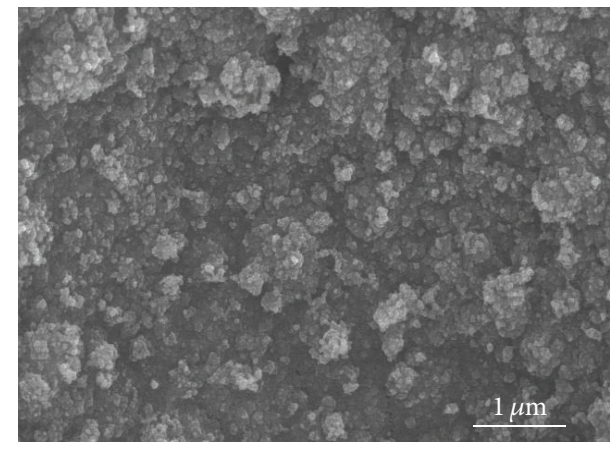

(a)

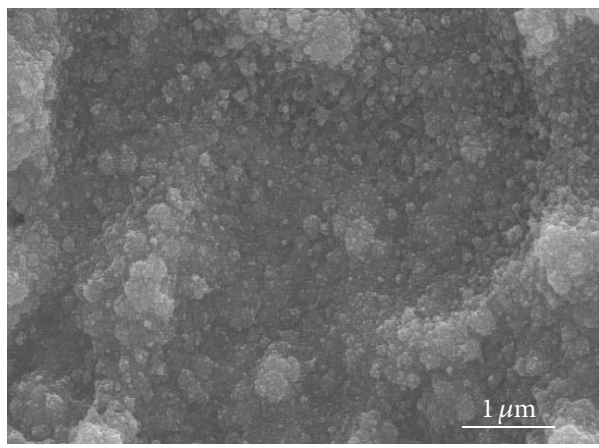

(c)

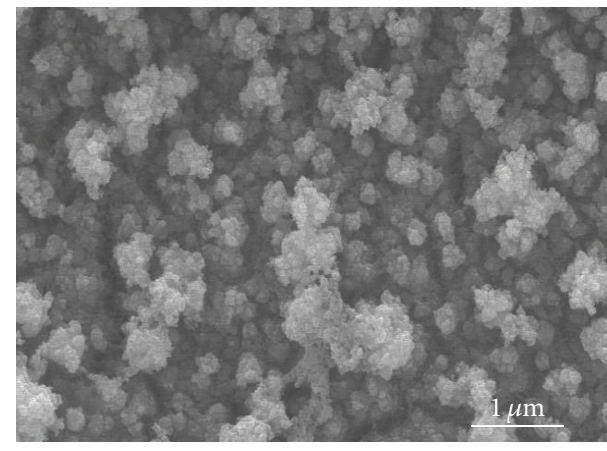

(b)

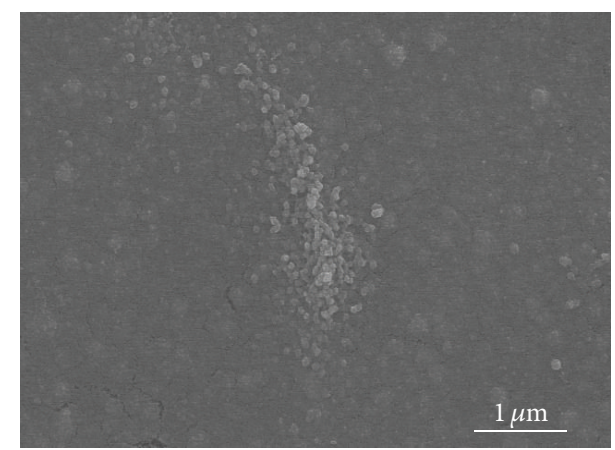

(d)

FIGURE 8: SEM micrographs of $\mathrm{La}_{2} \mathrm{O}_{2} \mathrm{CO}_{3}$ layers calcined at $700 \mathrm{~K}$ for $30 \mathrm{~min}$ after $30 \mathrm{~min}$ electrodeposition of $2.0 \mathrm{mg} / \mathrm{mL}$ of La ${ }^{3+}$ ions on Ti at (a) $200 \mathrm{~V}$, (b) $400 \mathrm{~V}$, (c) $600 \mathrm{~V}$, and (d) $1000 \mathrm{~V}$. 


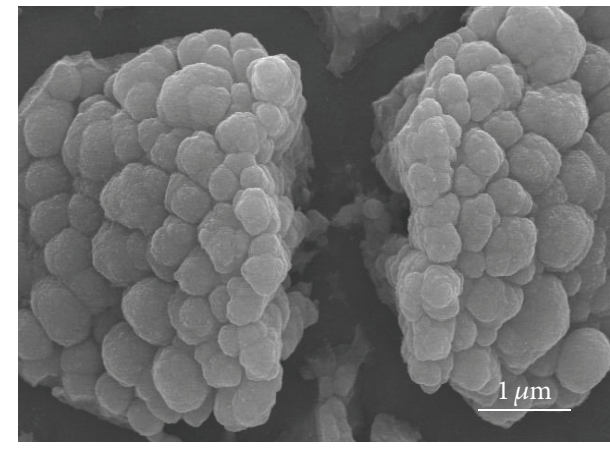

(a)

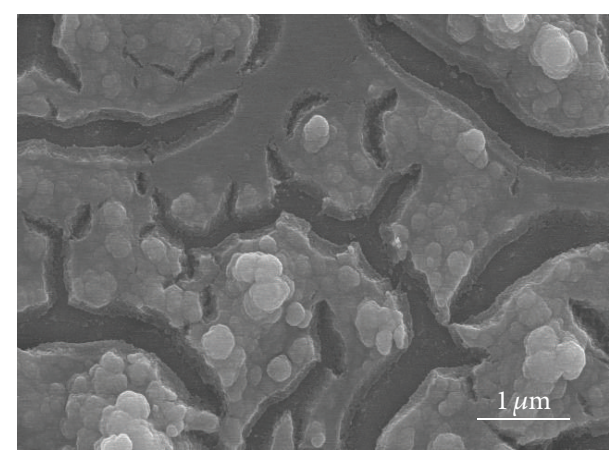

(c)

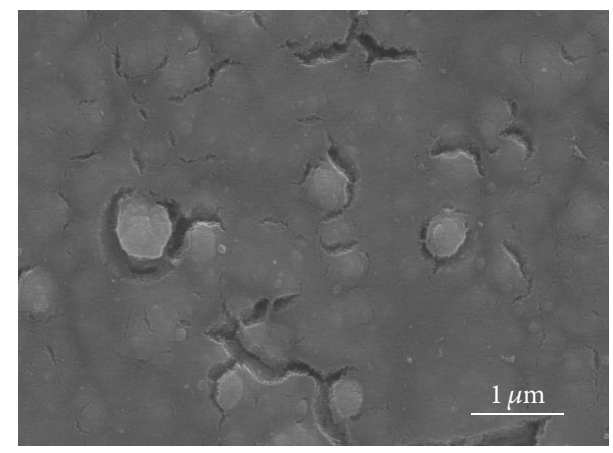

(b)

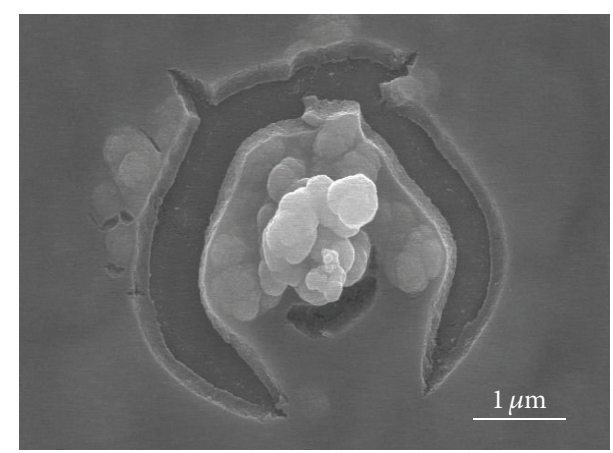

(d)

FIGURE 9: SEM micrographs of $\mathrm{La}_{2} \mathrm{O}_{2} \mathrm{CO}_{3}$ layers calcined at $700 \mathrm{~K}$ for $30 \mathrm{~min}$ after two $30 \mathrm{~min}$ electrodepositions of $0.046 \mathrm{mg} / \mathrm{mL}$ of $\mathrm{La}{ }^{3+}$ ions on $\mathrm{Ti}$ at (a) $200 \mathrm{~V}$, (b) $400 \mathrm{~V}$, (c) $600 \mathrm{~V}$, and (d) $1000 \mathrm{~V}$.

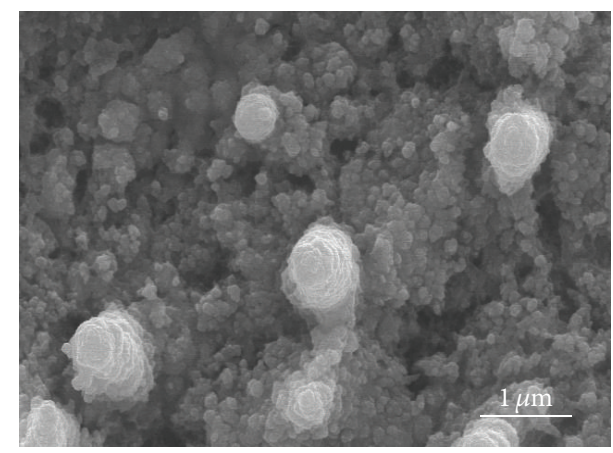

(a)

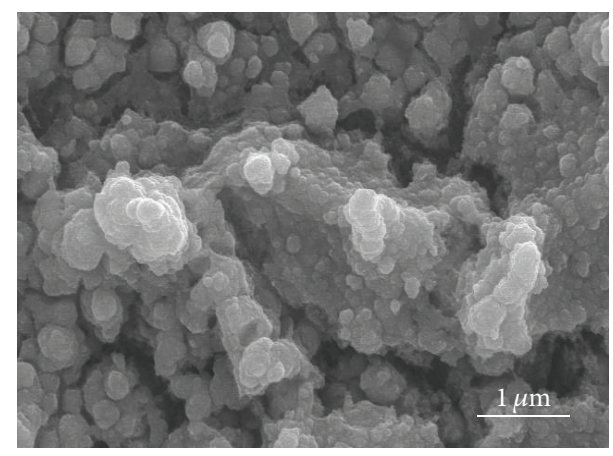

(c)

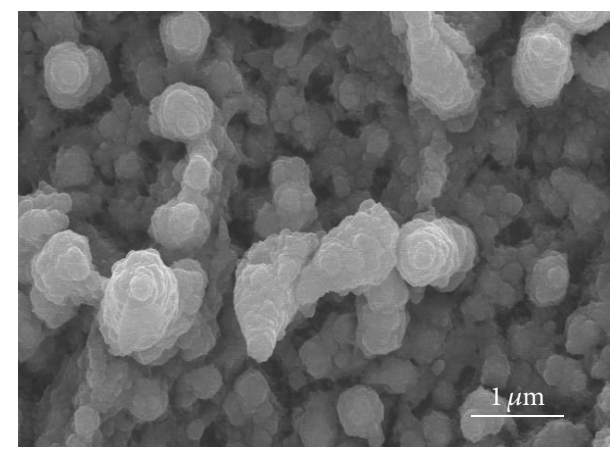

(b)

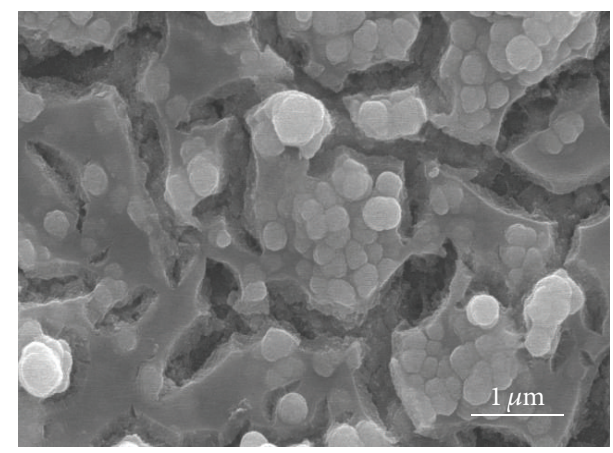

(d)

FIGURE 10: SEM micrographs of $\mathrm{La}_{2} \mathrm{O}_{2} \mathrm{CO}_{3}$ layers calcined at $700 \mathrm{~K}$ for $30 \mathrm{~min}$ after $30 \mathrm{~min}$ and $1 \mathrm{hr}$ electrodeposition of $0.092 \mathrm{mg} / \mathrm{mL}$ of $\mathrm{La}{ }^{3+}$ ions on Ti at (a) $200 \mathrm{~V}$, (b) $400 \mathrm{~V}$, (c) $600 \mathrm{~V}$, and (d) $1000 \mathrm{~V}$. 


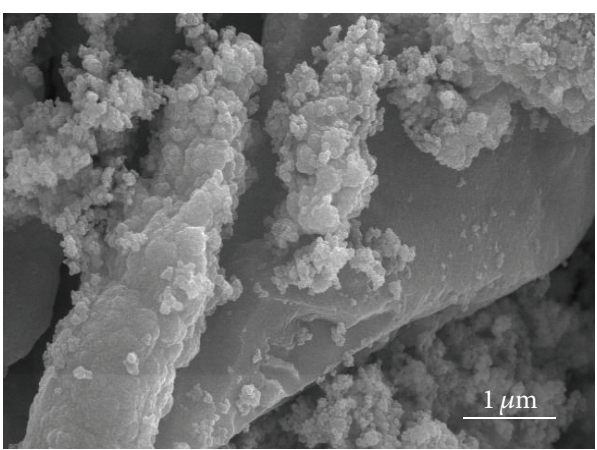

(a)

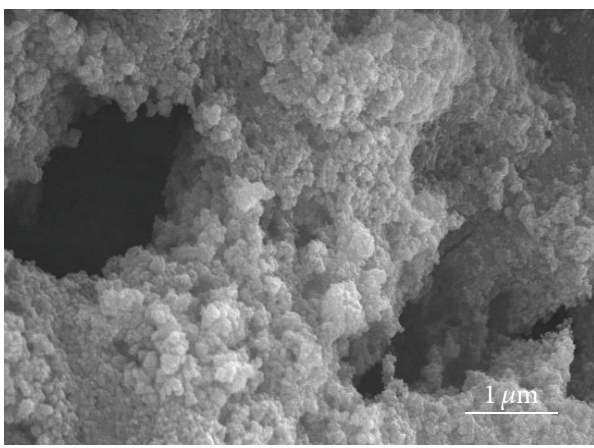

(c)

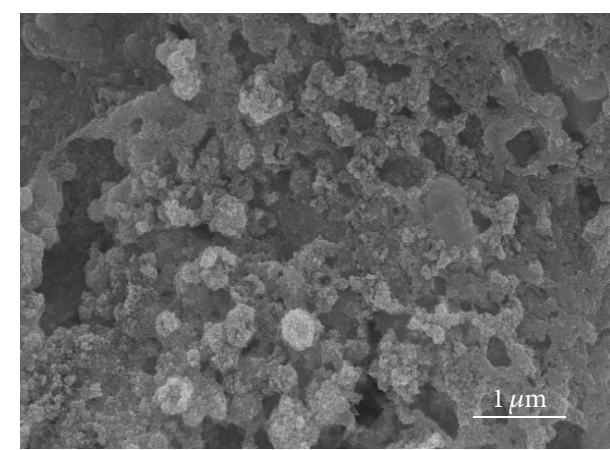

(b)

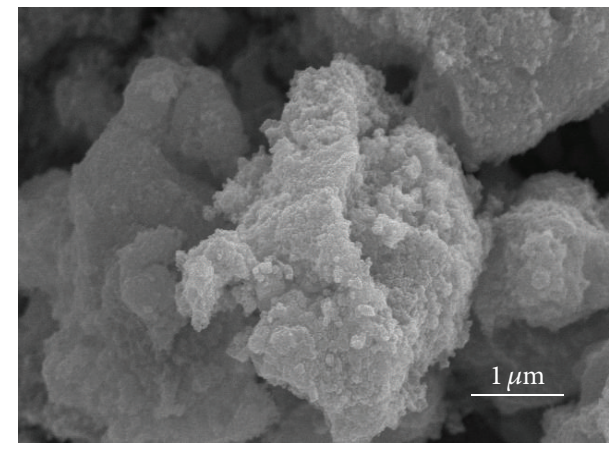

(d)

FIGURE 11: SEM micrographs of $\mathrm{La}_{2} \mathrm{O}_{2} \mathrm{CO}_{3}$ layers calcined at $700 \mathrm{~K}$ for $30 \mathrm{~min}$ after $30 \mathrm{~min}$ and $8 \mathrm{hr}$ electrodeposition of $2.0 \mathrm{mg} / \mathrm{mL}$ of La ${ }^{3+}$ ions on $\mathrm{Ti}$ at (a) $200 \mathrm{~V}$, (b) $400 \mathrm{~V}$, (c) $600 \mathrm{~V}$, and (d) $1000 \mathrm{~V}$.

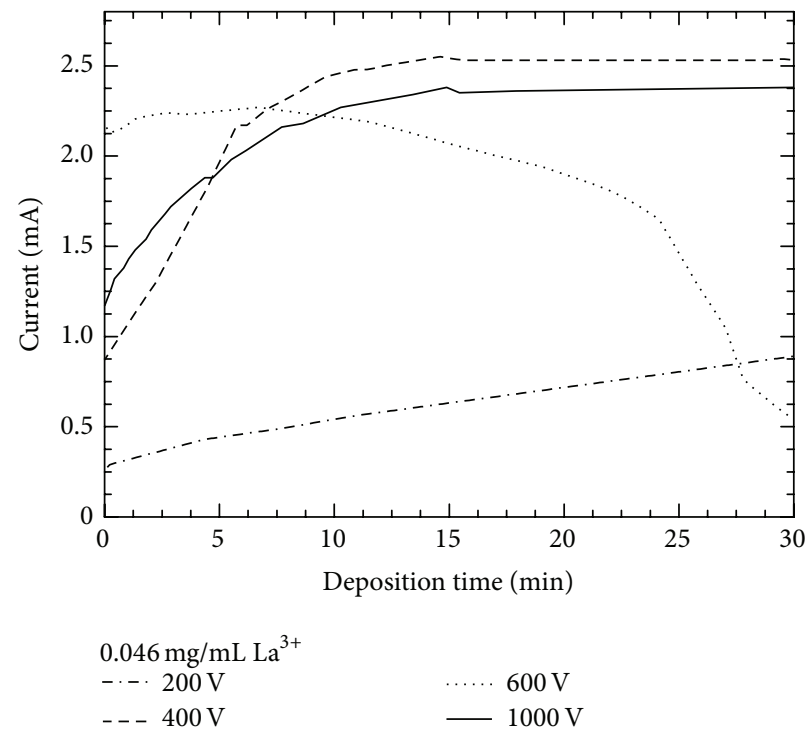

FIgURE 12: Currents of $30 \mathrm{~min}$ depositions with $0.046 \mathrm{mg} / \mathrm{mL}$ of $\mathrm{La}^{3+}$ ions at $200,400,600$, and $1000 \mathrm{~V}$.

finer agglomerates while the others contain a little larger agglomerates.

\section{Conclusions}

Layers of $\mathrm{La}_{2} \mathrm{O}_{2} \mathrm{CO}_{3}$ with various thicknesses ranging from 0.04 to $2.3 \mathrm{mg} / \mathrm{cm}^{2}$ along with $\mathrm{La}_{2} \mathrm{O}_{3}$ layers have been produced on Ti by electrodeposition of $\mathrm{La}^{3+}$ ions in isobutanol and subsequent calcination. Layers calcined at $700 \mathrm{~K}$ for 30 min turned out to be $\mathrm{La}_{2} \mathrm{O}_{2} \mathrm{CO}_{3}$ mainly with monoclinic phase and partially with tetragonal phase. Layers calcined at $900 \mathrm{~K}$ for $200 \mathrm{~min}$ were observed to contain $72 \% \mathrm{La}_{2} \mathrm{O}_{3}$ with hexagonal phase and $28 \% \mathrm{La}_{2} \mathrm{O}_{2} \mathrm{CO}_{3}$. The average particle size of $\mathrm{La}_{2} \mathrm{O}_{2} \mathrm{CO}_{3}$ decreases from 16 to $8 \mathrm{~nm}$ as calcination 


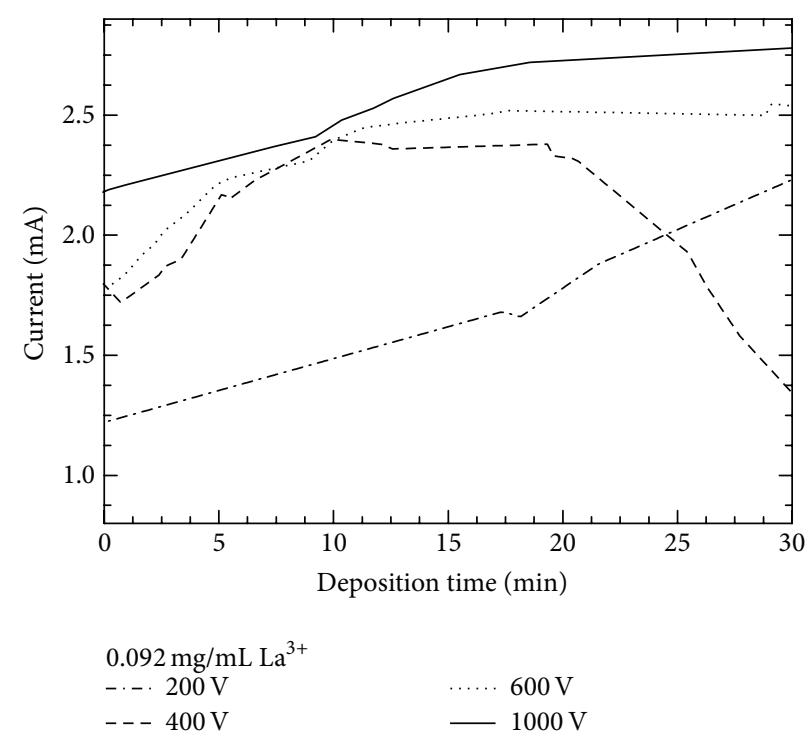

FIgUre 13: Currents of $30 \mathrm{~min}$ depositions with $0.092 \mathrm{mg} / \mathrm{mL}$ of $\mathrm{La}^{3+}$ ions at 200, 400, 600, and $1000 \mathrm{~V}$.

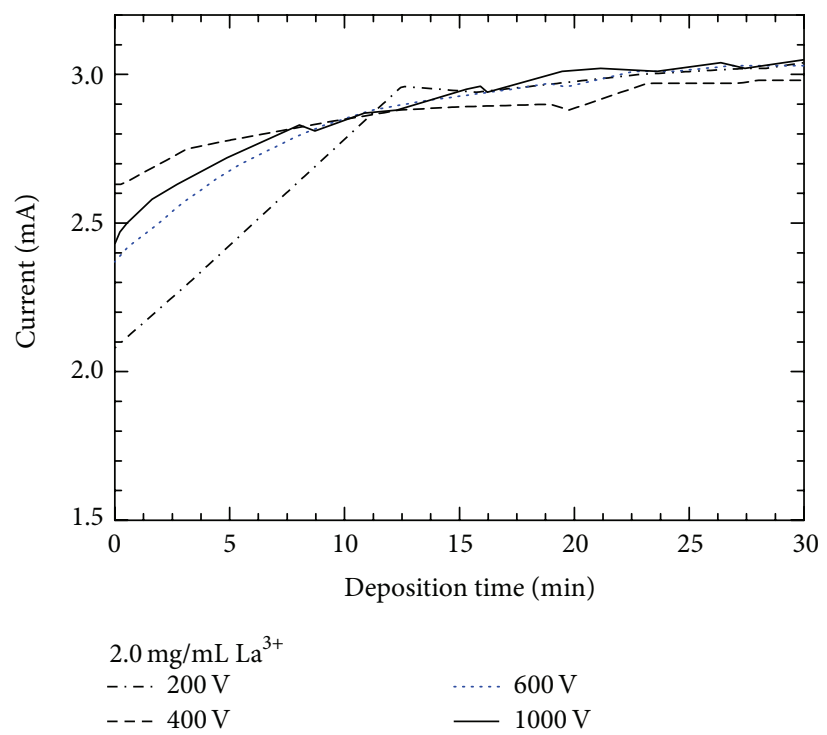

FIGURE 14: Currents of 30 min depositions with $2.0 \mathrm{mg} / \mathrm{mL}$ of $\mathrm{La}^{3+}$ ions at 200, 400, 600, and $1000 \mathrm{~V}$.

temperature and time increases from 700 to $900 \mathrm{~K}$ and from 30 to $200 \mathrm{~min}$, respectively. Dependence of the layer thickness on the electrodeposition voltage in this range was not pronounced, even though the morphology varies slightly with the voltage. Currents and yields with three concentrations of lanthanum ions were shown to be enhanced at $400 \mathrm{~V}$. The layer thicknesses with lanthanum concentrations of 0.046 , 0.092 , and $2.0 \mathrm{mg} / \mathrm{mL}$ were $0.04-0.05,0.09-0.13$, and $0.38-$ $0.46 \mathrm{mg} / \mathrm{cm}^{2}$, respectively. The sizes of their agglomerates were ranging from 25 to $75 \mathrm{~nm}$. Using 5 or 6 steps of the 30 min electrodeposition and subsequent $30 \mathrm{~min}$ calcination process, thicker layers of $\mathrm{La}_{2} \mathrm{O}_{2} \mathrm{CO}_{3}$ were prepared at 200 , 400,600 , and $1000 \mathrm{~V}$ and the corresponding thicknesses were $2.0,2.3,2.3$, and $2.0 \mathrm{mg} / \mathrm{cm}^{2}$, respectively. The sizes of their agglomerates were ranging from 44 to $2200 \mathrm{~nm}$. Lanthanum oxycarbonate nanoparticles with agglomerates of various sizes are to be tested as sensing materials in photocatalytic activity and wastewater purification.

\section{Competing Interests}

The authors declare that they have no competing interests.

\section{Acknowledgments}

This work was financially supported by Hallym University (HRF-201501-011). 


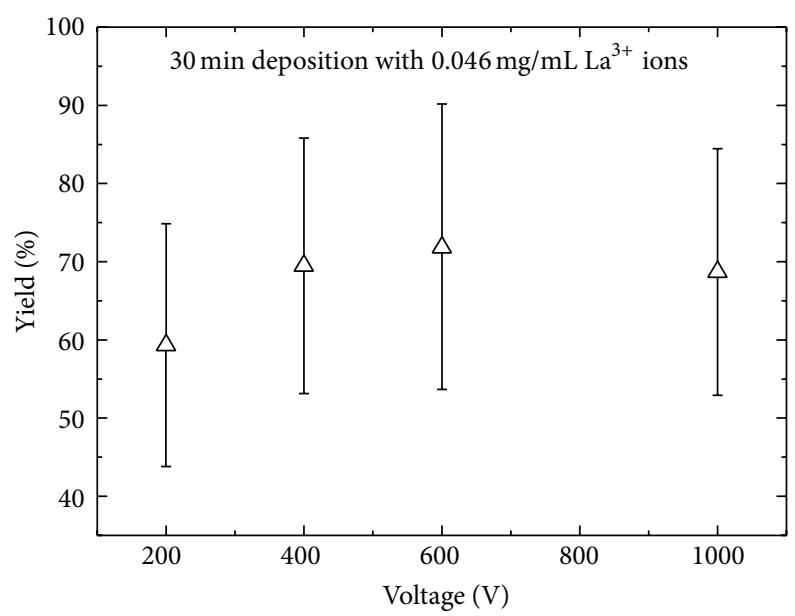

FIgURE 15: Yields of $30 \mathrm{~min}$ depositions with $0.046 \mathrm{mg} / \mathrm{mL}$ of $\mathrm{La}^{3+}$ ions at $200,400,600$, and $1000 \mathrm{~V}$.

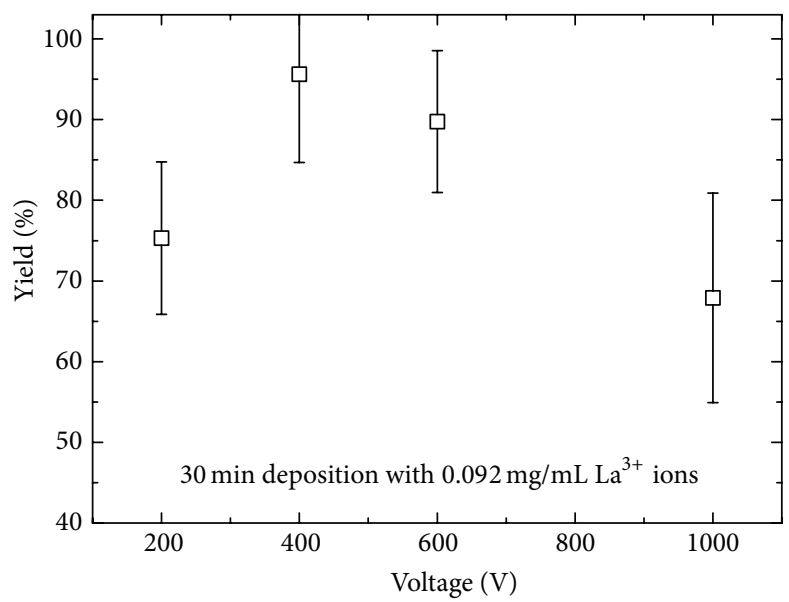

FIGURE 16: Yields of $30 \mathrm{~min}$ depositions with $0.092 \mathrm{mg} / \mathrm{mL}$ of $\mathrm{La}^{3+}$ ions at 200, 400, 600, and $1000 \mathrm{~V}$.

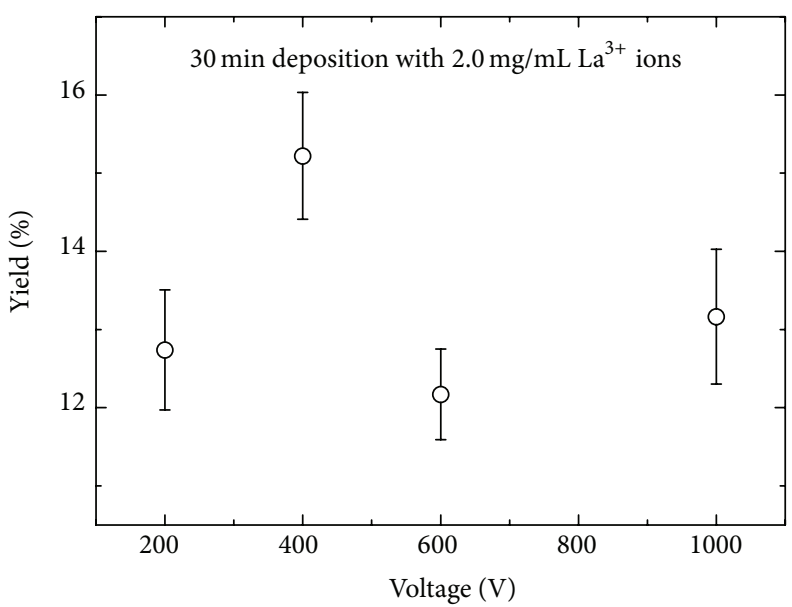

FIGURE 17: Yields of $30 \mathrm{~min}$ depositions with $2.0 \mathrm{mg} / \mathrm{mL}$ of $\mathrm{La}^{3+}$ ions at 200, 400, 600, and $1000 \mathrm{~V}$. 


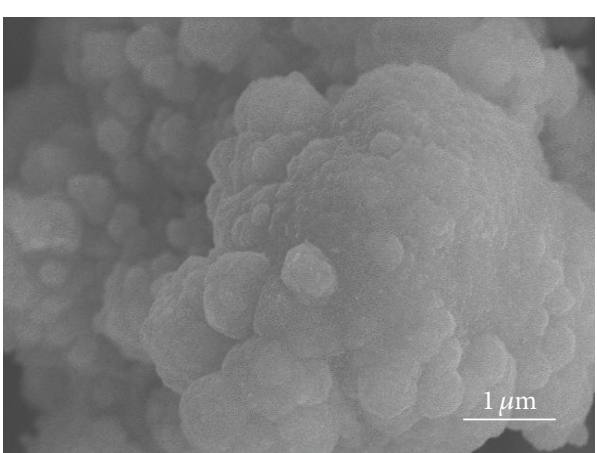

(a)

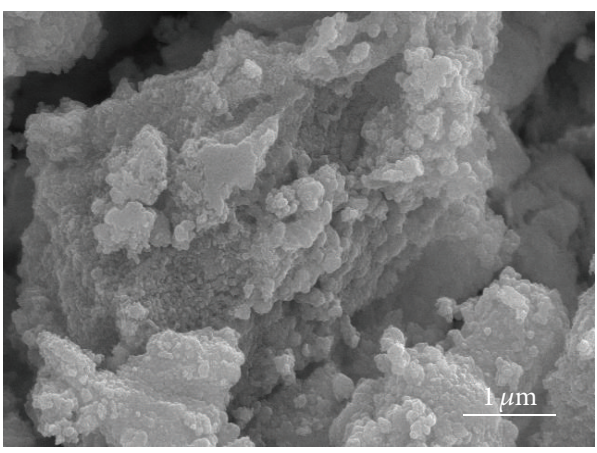

(c)

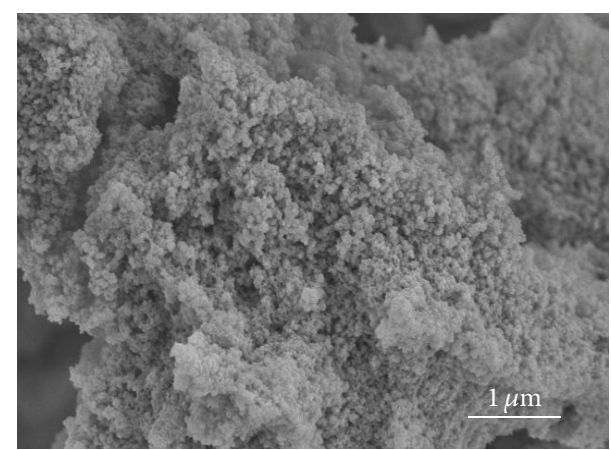

(b)

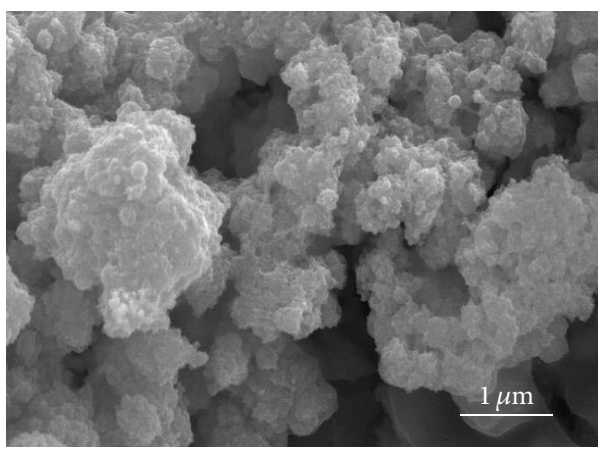

(d)

FIGURE 18: SEM micrographs of $\mathrm{La}_{2} \mathrm{O}_{2} \mathrm{CO}_{3}$ layers obtained by 5-6 steps of 30 min calcination at $700 \mathrm{~K}$ following 30 min electrodeposition of $2.0 \mathrm{mg} / \mathrm{mL}$ of La${ }^{3+}$ ions on Ti at (a) $200 \mathrm{~V}$, (b) $400 \mathrm{~V}$, (c) $600 \mathrm{~V}$, and (d) $1000 \mathrm{~V}$.

\section{References}

[1] Y. V. Lobanov, G. V. Buklanov, F. S. Abdullin et al., "Targets of uranium, plutonium, and curium for heavy-element research," Nuclear Instruments and Methods in Physics Research, Section A: Accelerators, Spectrometers, Detectors and Associated Equipment, vol. 397, no. 1, pp. 26-29, 1997.

[2] C. Vermeulen, G. F. Steyn, F. M. Nortier, F. Szelecsényi, Z. Kovács, and S. M. Qaim, "Production of ${ }^{139} \mathrm{Ce}$ by protoninduced reactions on ${ }^{141} \mathrm{Pr}$ and ${ }^{\text {nat }} \mathrm{La}$," Nuclear Instruments and Methods in Physics Research Section B: Beam Interactions with Materials and Atoms, vol. 255, no. 2, pp. 331-337, 2007.

[3] M. Murakami, H. Haba, S. Goto, J. Kanaya, and H. Kudo, "Production cross sections of niobium and tantalum isotopes in proton-induced reactions on ${ }^{\text {nat }} \mathrm{Zr}$ and ${ }^{\text {nat }} \mathrm{Hf}$ up to $14 \mathrm{MeV}$," Applied Radiation and Isotopes, vol. 90, pp. 149-157, 2014.

[4] J. Wing and J. R. Huizenga, “ $(p, n)$ cross sections of $\mathrm{V}^{51}, \mathrm{Cr}^{52}$, $\mathrm{Cu}^{63}, \mathrm{Cu}^{65}, \mathrm{Ag}^{107}, \mathrm{Ag}^{109}, \mathrm{Cd}^{111}, \mathrm{Cd}^{114}$, and $\mathrm{La}^{139}$ from 5 to 10.5 MeV," Physical Review, vol. 128, no. 1, pp. 280-290, 1962.

[5] H. E. Hassan, F. S. Al-Saleh, K. F. Hassan, A. Sayaed, and Z. A. Saleh, "Proton induced reactions on Tb-159 and La139 for producing Dy and Ce-139," in Proceedings of the 6th International Conference on Nuclear and Particle Physics, p. 209, Luxor, Egypt, 2007.

[6] G. Albouy, M. Gusakow, N. Poffé, H. Sergolle, and L. Valentin, "Réactions ( $\mathrm{p}, \mathrm{n})$ à moyenne énergie," Journal de Physique et le Radium, vol. 23, no. 12, pp. 1000-1002, 1962.

[7] H. C. Aspinall, J. Gaskell, P. A. Williams et al., "Growth of lanthanum oxide thin films by liquid injection MOCVD using a novel lanthanum alkoxide precursor," Chemical Vapor Deposition, vol. 10, no. 1, pp. 13-17, 2004.

[8] M. Nieminen, M. Putkonen, and L. Niinistö, "Formation and stability of lanthanum oxide thin films deposited from $\beta$ diketonate precursor," Applied Surface Science, vol. 174, no. 2, pp. 155-165, 2001.

[9] S. S. Kale, K. R. Jadhav, P. S. Patil, T. P. Gujar, and C. D. Lokhande, "Characterizations of spray-deposited lanthanum oxide $\left(\mathrm{La}_{2} \mathrm{O}_{3}\right)$ thin films," Materials Letters, vol. 59, no. 24-25, pp. 3007-3009, 2005.

[10] F. J. Jing, L. Wang, Y. W. Liu et al., "Hemocompatibility of lanthanum oxide films fabricated by dual plasma deposition," Thin Solid Films, vol. 515, no. 3, pp. 1219-1222, 2006.

[11] M. Ghiasi and A. Malekzadeh, "Synthesis, characterization and photocatalytic properties of lanthanum oxy-carbonate, lanthanum oxide and lanthanum hydroxide nanoparticles," Superlattices and Microstructures, vol. 77, pp. 295-304, 2015.

[12] A. N. Shirsat, M. Ali, K. N. G. Kaimal, S. R. Bharadwaj, and D. Das, "Thermochemistry of $\mathrm{La}_{2} \mathrm{O}_{2} \mathrm{CO}_{3}$ decomposition," Thermochimica Acta, vol. 399, no. 1-2, pp. 167-170, 2003.

[13] Q. Shi, Z. Peng, W. Chen, and N. Zhang, " $\mathrm{La}_{2} \mathrm{O}_{2} \mathrm{CO}_{3}$ supported $\mathrm{Ni}-\mathrm{Fe}$ catalysts for hydrogen production from steam reforming of ethanol," Journal of Rare Earths, vol. 29, no. 9, pp. 861-865, 2011.

[14] H. Niu, Q. Min, Z. Tao et al., "One-pot facile synthesis and optical properties of porous $\mathrm{La}_{2} \mathrm{O}_{2} \mathrm{CO}_{3}$ hollow microspheres," Journal of Alloys and Compounds, vol. 509, no. 3, pp. 744-747, 2011.

[15] A. Pons, J. Jouin, E. Béchade et al., "Study of the formation of the apatite-type phases $\mathrm{La}_{9.33+x}\left(\mathrm{SiO}_{4}\right) 6 \mathrm{O}_{2+3 x / 2}$ synthesized from 
a lanthanum oxycarbonate $\mathrm{La}_{2} \mathrm{O}_{2} \mathrm{CO}_{3}$," Solid State Sciences, vol. 38, pp. 150-155, 2014.

[16] G. Chen, B. Han, S. Deng, Y. Wang, and Y. Wang, "Lanthanum dioxide carbonate $\mathrm{La}_{2} \mathrm{O}_{2} \mathrm{CO}_{3}$ nanorods as a sensing material for chemoresistive $\mathrm{CO}_{2}$ gas sensor," Electrochimica Acta, vol. 127, pp. 355-361, 2014.

[17] W. Parker and M. Colonomos, "Preparation of thin layers of ${ }^{237} \mathrm{~Np}$ for absolute counting and fission detectors," Nuclear Instruments and Methods, vol. 66, no. 1, pp. 137-140, 1968.

[18] K. B. Lee, J. M. Lee, T. S. Park, and P.-J. Oh, "Preparation and activity measurement of electrodeposited alpha-emitting sources," Applied Radiation and Isotopes, vol. 64, no. 10-11, pp. 1260-1264, 2006.

[19] P. G. Hansen, "The conditions for electrodeposition of insoluble hydroxides at a cathode surface: a theoretical investigation," Journal of Inorganic and Nuclear Chemistry, vol. 12, no. 1-2, pp. 30-37, 1959.

[20] M. T. Crespo, "A review of electrodeposition methods for the preparation of alpha-radiation sources," Applied Radiation and Isotopes, vol. 70, no. 1, pp. 210-215, 2012.

[21] S. Takács, F. Tárkányi, M. Sonck, and A. Hermanne, "New crosssections and intercomparison of proton monitor reactions on $\mathrm{Ti}, \mathrm{Ni}$ and $\mathrm{Cu}$," Nuclear Instruments and Methods in Physics Research, Section B: Beam Interactions with Materials and Atoms, vol. 188, no. 1-4, pp. 106-111, 2002.

[22] K. Gul, A. Hermanne, M. G. Mustafa et al., "Charged particle cross-section database for medical radioisotope production: diagnostic and monitor reactions," Tech. Rep. IAEA-TECDOC1211, International Atomic Energy Agency, Vienna, Austria, 2001.

[23] M. Salavati-Niasari, G. Hosseinzadeh, and F. Davar, "Synthesis of lanthanum hydroxide and lanthanum oxide nanoparticles by sonochemical method," Journal of Alloys and Compounds, vol. 509, no. 10, pp. 4098-4103, 2011. 

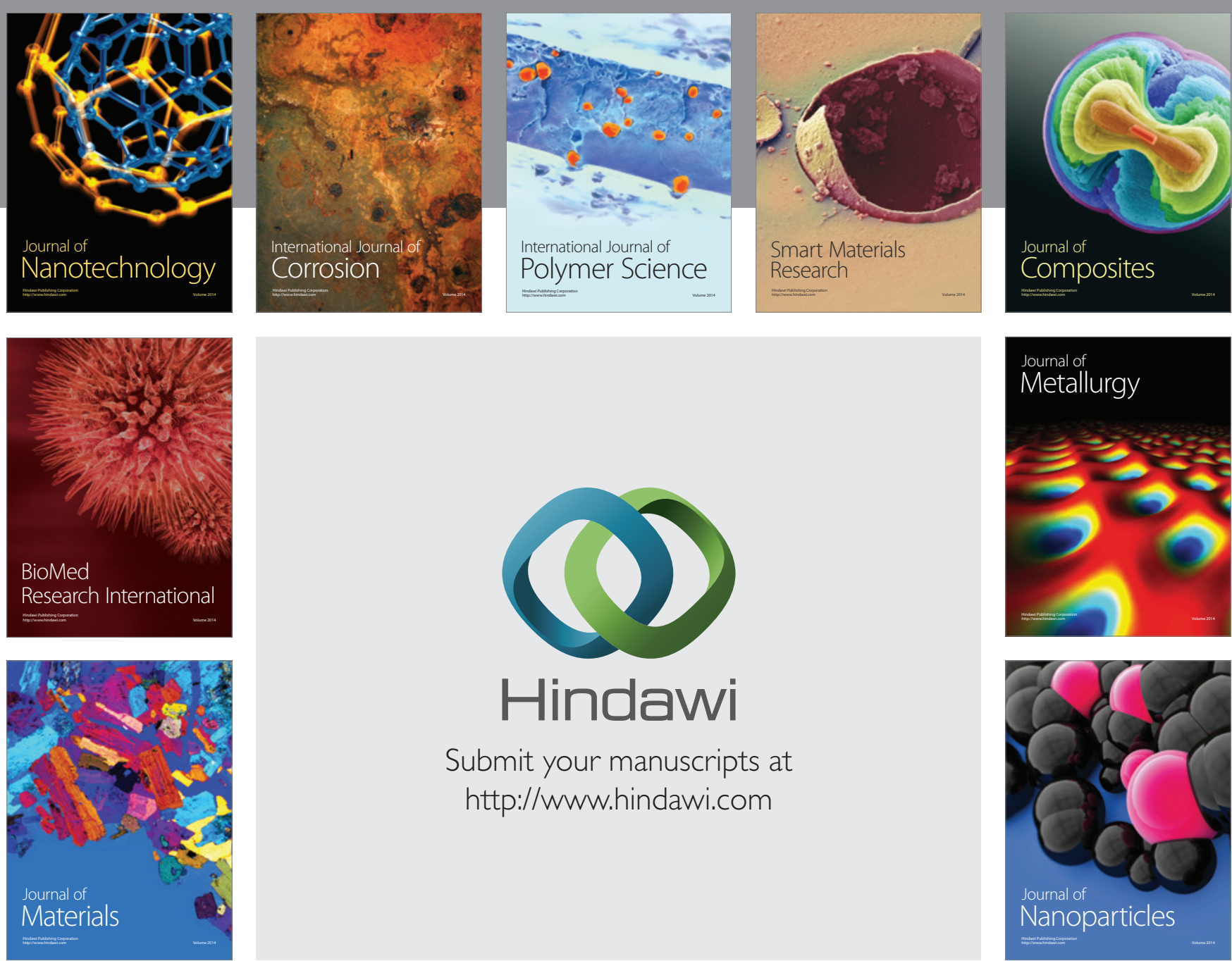

\section{Hindawi}

Submit your manuscripts at

http://www.hindawi.com

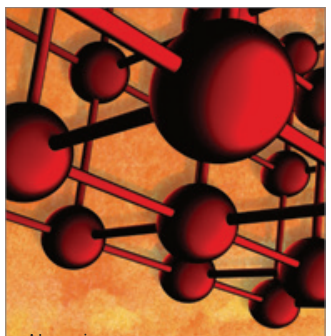

Materials Science and Engineering
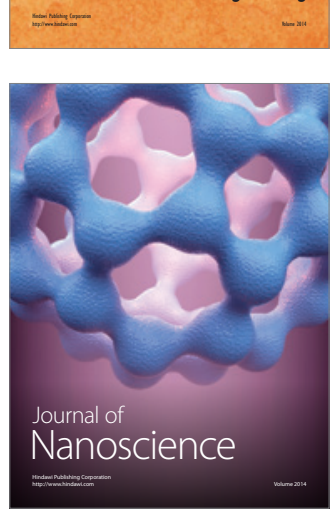
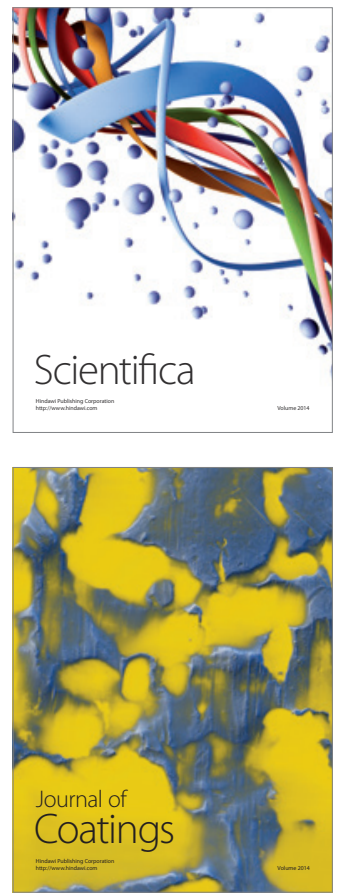
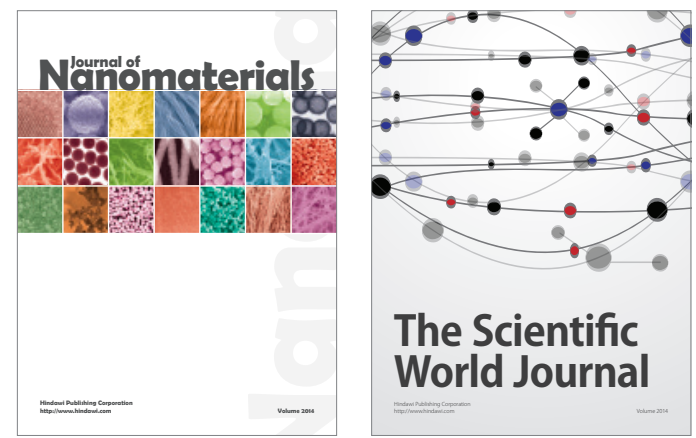

The Scientific World Journal
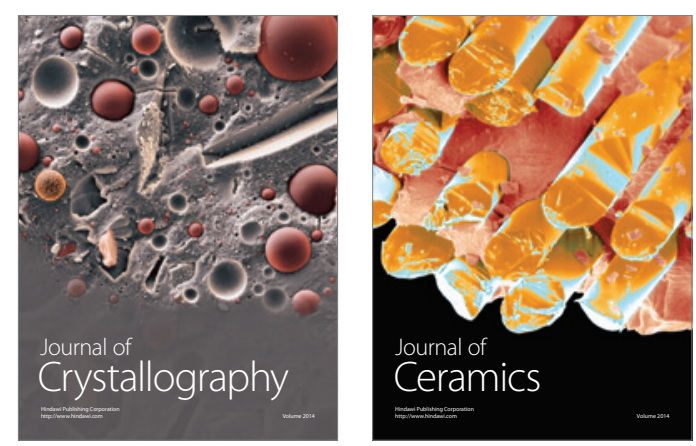
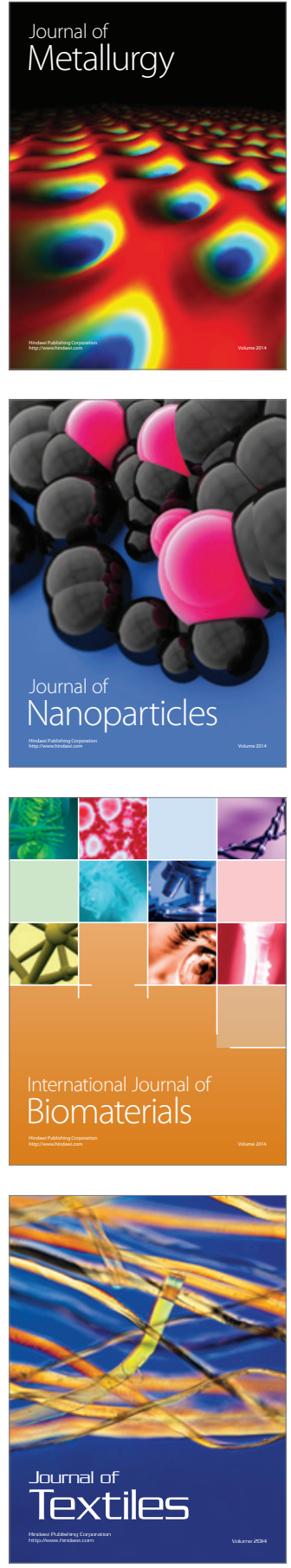